\title{
Originals
}

\section{HLA antigens and risk factors for nephropathy in Type 1 (insulin-dependent) diabetes mellitus}

\author{
C. Walton ${ }^{1}$, P.A. Dyer ${ }^{2}$, J.A. Davidson ${ }^{2}$, R. Harris ${ }^{2}$, N.P. Mallick ${ }^{1}$ and S.Oleesky ${ }^{1}$ \\ ${ }^{1}$ M3 Unit, Manchester Royal Infirmary and 2Department of Medical Genetics, Saint Mary's Hospital, Manchester, UK
}

\begin{abstract}
Summary. This study of risk factors for diabetic nephropathy in juvenile Type 1 (insulin-dependent) diabetes mellitus compares two carefully characterised groups of patients, one with proteinuria $(n=23)$, the other a control group $(n=24)$ with no evidence of nephropathy despite more than 25 years of diabetic life. No significant difference was observed between the groups in any HLA-A, -B or -DR antigen or Bf allotype. DR3 was present in $87 \%$ of patients with proteinuria and $75 \%$ of the diabetic control group; DR4 was present in $48 \%$ of patients with proteinuria and $63 \%$ of diabetic controls; $\mathrm{BfFl}$ was present in $17 \%$ of patients with nephropathy and $9 \%$ of the diabetic control group. Compared with the control group, patients with proteinuria had significantly higher mean diabetic-
\end{abstract}

clinic blood glucose concentrations before the diagnosis of microvascular disease, a significantly earlier age at diagnosis of diabetes, and had more often been treated with once-daily as opposed to twice-daily insulin regimens. Susceptibility to nephropathy in Type 1 diabetes appears to be determined by the quality of metabolic control and age of onset of diabetes; although the number of subjects studied was relatively small no evidence was found of any influence of HLA or Bf phenotype.

Key words: Type 1 diabetes, nephropathy, risk factors, HLA antigens.
Without treatment for renal failure a young diabetic who develops proteinuria, the clinical marker of diabetic nephropathy, is likely to be dead within 12 years [1]. However, those who survive more than 40 years of diabetes are free of proteinuria in over $70 \%$ of cases $[2,3]$. Although the quality of metabolic control may be important [4], there is evidence that other, as yet unknown, factors may predetermine or protect against this complication [5].

Type 1 diabetes is strongly associated with HLA antigens DR3 and DR4 [6]. If there is an association between DR4 and retinopathy in Type 1 diabetes, as has been both claimed [7, 8] and denied [9], a similar relationship may exist for nephropathy. On the other hand, DR3 is associated with certain forms of renal disease in non-diabetic subjects $[10,11]$, so diabetic patients possessing DR3 may be at greater risk of nephropathy.

To test these hypotheses we have studied major histocompatibility system class I (HLA-A,-B) class II (HLA-DR) and class III (Bf) gene products and clinical features in two groups of patients with Type 1 diabetes diagnosed before the age of 30 years, one with nephropathy and the other free of nephropathy after more than 25 years of diabetic life.

\section{Subjects and methods}

\section{Patients}

Patients were recruited from the diabetic clinic at Manchester Royal Infirmary after scrutiny of the diabetic clinic records over a 9-month period. Criteria for inclusion in the study were insulin treatment from within 6 months of diagnosis and documentation in the patient's records of either ketonuria at diagnosis or an episode of ketoacidosis. Only patients of European Caucasoid race and diagnosed before the age of 30 years were selected. Twenty-three unrelated patients with Type 1 diabetes and diabetic nephropathy were studied. Nephropathy was defined as persistent proteinuria (Albustix) on at least four consecutive clinic visits over a period exceeding one year, and a $24-\mathrm{h}$ protein excretion $>0.5 \mathrm{~g}$. Elevated plasma creatinine values were present in 12 patients $(>120 \mu \mathrm{mol} / \mathrm{l})$, but only three were in end-stage renal failure.

No patient had clinical evidence of renal disease distinct from diabetic nephropathy. Intravenous pyelography had been performed on 14 patients; renal size was normal in 13 and bilaterally increased in one nephrotic patient. Renal histology showing diffuse glomerulosclerosis with or without nodular glomerulosclerosis was known in four patients, including two of four who had no diabetic retinopathy on direct ophthalmoscopy.

As a control group, 24 unrelated patients who had survived $>25$ years of diabetic life without developing proteinuria (Albustix) were recruited. All had normal plasma creatinine values $(<$ $120 \mu \mathrm{mol} / \mathrm{l})$ and $24-\mathrm{h}$ urinary protein excretion $(<0.2 \mathrm{~g})$. Details of distribution of age and sex, duration of diabetes, duration of protein- 
Table 1. Clinical details of diabetic patients with and without nephropathy

\begin{tabular}{|c|c|c|c|c|c|c|c|c|c|c|c|c|c|c|c|c|c|c|c|}
\hline & \multirow{4}{*}{$\begin{array}{l}\text { Sex } \\
\text { ratio } \\
M: F\end{array}$} & \multirow{2}{*}{\multicolumn{2}{|c|}{$\begin{array}{l}\text { Duration of } \\
\text { diabetes } \\
\text { (years) }\end{array}$}} & \multirow{2}{*}{\multicolumn{2}{|c|}{$\begin{array}{l}\text { Duration of } \\
\text { proteinuria } \\
\text { (years) }\end{array}$}} & \multicolumn{6}{|c|}{ Patients with retinopathy ${ }^{b}$} & \multirow{4}{*}{$\begin{array}{l}\% \text { of ideal } \\
\text { body } \\
\text { weight }^{c}\end{array}$} & \multirow{4}{*}{$\begin{array}{l}\text { Daily insu- } \\
\text { lin dose } \\
\text { ( } \mathrm{u} / \mathrm{kg} \text { body } \\
\text { weight) }\end{array}$} & \multicolumn{6}{|c|}{ Frequency of insulin injections } \\
\hline & & & & & & \multirow{2}{*}{\multicolumn{2}{|c|}{$\begin{array}{l}\text { None } \\
\overline{\text { No. } \%}\end{array}$}} & \multirow{2}{*}{\multicolumn{2}{|c|}{$\frac{\begin{array}{l}\text { Back- } \\
\text { ground }\end{array}}{\text { No. } \%}$}} & \multicolumn{2}{|c|}{$\begin{array}{l}\text { Prolifer- } \\
\text { ative }\end{array}$} & & & \multirow{2}{*}{\multicolumn{2}{|c|}{$\begin{array}{l}\text { Once } \\
\text { daily }\end{array}$}} & \multirow{2}{*}{\multicolumn{2}{|c|}{$\begin{array}{l}\text { Twice } \\
\text { daily }\end{array}$}} & \multirow{2}{*}{\multicolumn{2}{|c|}{$\begin{array}{l}\text { Varying be- } \\
\text { tween once } \\
\text { and twice } \\
\text { daily }\end{array}$}} \\
\hline & & \multirow{2}{*}{ Median } & \multirow{2}{*}{ Range } & \multirow{2}{*}{ Median } & \multirow{2}{*}{ Range } & & & & & \multirow[t]{2}{*}{ No. } & \multirow[t]{2}{*}{$\%$} & & & & & & & & \\
\hline & & & & & & & & & & & & & & No. & & No. & $\%$ & No. & $\%$ \\
\hline $\begin{array}{l}\text { Diabetic patients with } \\
\text { nephropathy }(n=23)\end{array}$ & $14: 9$ & 20 & $8-35$ & 4 & $1-15$ & 4 & 17 & 5 & 22 & 14 & 61 & $113 \pm 16$ & $0.75 \pm 0.23$ & 11 & 48 & 6 & 26 & 6 & 26 \\
\hline $\begin{array}{c}\text { Diabetic patients without } \\
\text { nephropathy }(n=24)\end{array}$ & $15: 9$ & 37.5 & $26-52$ & - & - & 13 & 54 & 7 & 29 & 4 & 17 & $111 \pm 13$ & $0.70 \pm 0.24$ & 2 & 8 & 17 & 71 & 5 & 21 \\
\hline
\end{tabular}

Results expressed as mean \pm SD. $\quad \mathrm{b}$ None $=<$ five microaneurysms, no exudates or haemorrhages. Background $=$ at least one hard exudate, one haemorrhage or five or more microaneurysms. No new vessels. Proliferative $=$ new vessel formation; c calculated using Bull. Metrop. Life Insur. Co. (1959) 40

uria if present, retinopathy, body weight and insulin dosage are given in Table 1.

\section{Clinical information}

Each patient was interviewed and questioned regarding date of diagnosis of diabetes, past and present insulin regimens, insulin dosage, family history of Type 1 diabetes or renal disease in first degree relatives, emergency visits and admissions to hospital because of ketoacidosis or hypoglycaemia, autoimmune thyroid disease (thyrotoxicosis, Hashimoto's disease or myxoedema), occupation, smoking habits and alcohol consumption. Height and weight were recorded and the retinae examined by direct ophthalmoscopy after pupillary dilatation. Most patients with retinopathy had also been examined by ophthalmologists and subjected to fundal photography and fluorescein angiography. Patient records from the Manchester Royal Infirmary (and where appropriate from other hospitals) were reviewed to confirm information obtained at interview, and to document duration of proteinuria, date of first observation of retinopathy and all blood glucose concentrations measured at afternoon diabetic clinics prior to the first record of either retinopathy or proteinuria. Individual mean blood glucose concentrations were calculated from the blood glucose concentrations obtained at diabetic clinics. No previous blood glucose recordings were available on four patients with nephropathy who had been referred to the diabetic clinic with evidence of microvascular disease after long periods without medical supervision. A total of 758 blood glucose recordings (median 40, range 4-102) were available on the remaining 19 patients with nephropathy and 1,794 blood glucose recordings (median 75, range 15-177) on the 24 patients without nephropathy. Patients were divided into those treated with once-daily and those with twice-daily insulin, provided that their insulin treatment had not deviated from the stated frequency for a period exceeding one year. A positive history of smoking was defined as the regular smoking of any amount of cigarettes or tobacco for a period exceeding half the patient's diabetic life after the age of 15 years. Patients were divided into social class according to the Registrar General's classification.

\section{Immunological methods}

Individuals were tested for 12 HLA-A and 18 HLA-B antigens using the standard National Institutes of Health lymphocytotoxicity technique. HLA-DR typing for antigens 1-10 was carried out on peripheral blood B lymphocytes isolated by their adherence to nylon wool columns [12]. All antisera were obtained locally and were characterised on cell panels tested with Seventh and Eighth Workshop antisera. Bf phenotypes were determined by high voltage electrophoresis of serum in agarose gels followed by immunofixation using an antiserum specific to properdin factor B (Atlantic antibodies).

\section{Other laboratory methods}

Urinary protein was estimated by an automated turbidimetric method using sulphosalicylic acid [13]. Plasma creatinine was measured by a Vickers M300 multichannel analyser (Vickers Medical, Basingstoke, Hants, UK) using a modified Jaffé reaction. Capillary blood glucose was assayed by a glucose oxidase method.

\section{Statistical methods}

Fisher's exact test was used to compare antigen frequencies in patients and control subjects. Clinical data were analysed using the Mann-Whitney U test, the $\chi^{2}$ test with Yates' correction and the Kendall rank correlation test. Two-tailed $p$ values were used throughout.

\section{Results}

\section{HLA and Bf typing}

There was no significant difference in the frequency of any HLA antigen or Bf allotype between the subjects with diabetic nephropathy and the diabetic controls. Table 2 shows the phenotype frequencies for certain gene products coded in the major histocompatibility system; only those known to be positively or negatively associated with Type 1 diabetes are included. All of the 14 patients with both diabetic nephropathy and proliferative retinopathy were positive for DR3, but only six had DR4.

\section{Age at diagnosis}

Median age at diagnosis of diabetes was 15 years (range 2-28 years) for patients with nephropathy and 21 years (range 2-29 years) for patients without nephropathy. The difference between the groups was significant $(p<$ 0.005 , Mann-Whitney U test).

\section{Mean blood glucose concentrations}

Diabetic patients with nephropathy had significantly higher mean blood glucose concentrations than those without nephropathy $(p<0.03$, Mann-Whitney $U$ test, Fig.1). A mean blood glucose concentration of < 
Table 2. HLA antigen and Bf allotype frequencies in Type 1 diabetic patients with and without nephropathy

\begin{tabular}{|c|c|c|c|c|c|c|c|c|c|c|c|c|c|c|c|c|c|c|c|c|c|c|c|c|}
\hline & \multicolumn{22}{|c|}{ HLA antigens } & \multicolumn{2}{|c|}{$\begin{array}{l}\text { Bf allotype } \\
\text { frequency } \\
\text { BfFl }\end{array}$} \\
\hline & \multicolumn{2}{|c|}{$\frac{\mathrm{A} 1}{\text { No. } \%}$} & \multicolumn{2}{|c|}{$\frac{\mathrm{A} 2}{\text { No. } \%}$} & \multicolumn{2}{|c|}{$\frac{\text { Aw30 }}{\text { No. } \%}$} & \multicolumn{2}{|c|}{$\frac{B 7}{\text { No. } \%}$} & \multicolumn{2}{|c|}{$\frac{\mathrm{B} 8}{\mathrm{No} . \%}$} & \multicolumn{2}{|c|}{$\frac{B 15}{\text { No. } \%}$} & \multicolumn{2}{|c|}{$\frac{\mathrm{B} 18}{\text { No. } \%}$} & \multicolumn{2}{|c|}{$\frac{\text { DR2 }}{\text { No. } \%}$} & \multicolumn{2}{|c|}{$\frac{\text { DR3 }}{\text { No. } \%}$} & \multicolumn{2}{|c|}{$\frac{\mathrm{DR} 4}{\text { No. } \%}$} & \multicolumn{2}{|c|}{$\frac{\mathrm{DR} 3 / \mathrm{DR} 4}{\text { No. } \%}$} & & \\
\hline $\begin{array}{l}\text { Diabetic patients with } \\
\text { nephropathy }(n=23)\end{array}$ & 10 & 44 & 13 & 57 & 2 & 9 & 3 & 13 & 14 & $61^{\mathrm{d}}$ & 3 & 13 & 4 & 17 & 1 & $4^{c}$ & 20 & $87^{d}$ & 11 & 48 & 8 & 35 & 4 & 17 \\
\hline Normal subjects ${ }^{\mathrm{a}}$ & & 34 & & 49 & & 4 & & 27 & & 28 & & 9 & & 5 & & 28 & & 27 & & 36 & & - & & 4 \\
\hline
\end{tabular}

Full data for all specificities determined can be supplied to interested parties.

${ }^{a}$ Randomly selected: For HLA-A and $-\mathrm{B} \mathrm{n}=230$, HLA-DR $\mathrm{n}=105, \mathrm{Bf} \mathrm{n}=137$; ${ }^{\mathrm{b}}$ heterozygotes; ${ }^{\mathrm{c}} p<0.05$, ${ }^{\mathrm{d}} p<0.01$, significance versus normal subjects (Fisher's exact probability test without correction for number of antigens tested)

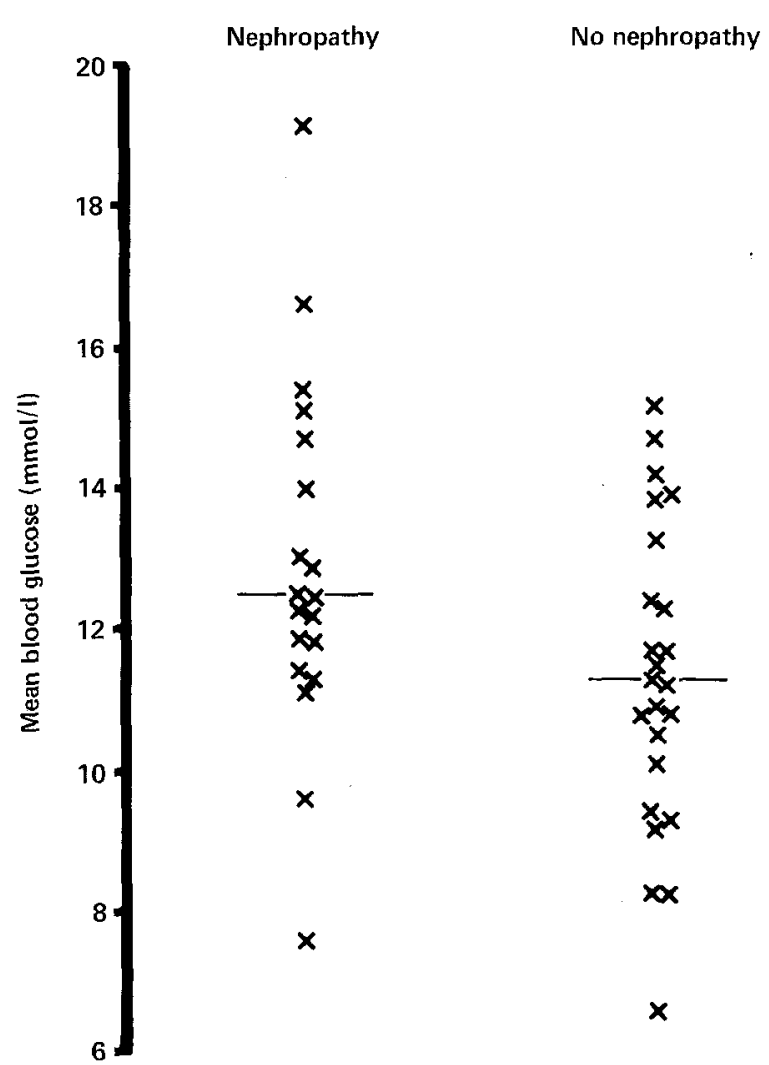

Fig. 1. Mean blood glucose concentrations in diabetic patients with nephropathy $(n=19)$ and without nephropathy $(n=24)$. Bars indicate median values; $p<0.03$

$11 \mathrm{mmol} / 1$ was observed in only two out of 19 patients with nephropathy compared with 11 out of 24 without nephropathy. There was no significant correlation between mean blood glucose concentration and age at diagnosis (Kendall rank correlation, $\tau=-0.12, p>0.1$ ).

\section{Insulin regimens}

There was a significant difference in the frequency of insulin injections between patients with and without ne- phropathy ( $p<0.02, \chi^{2}$ test). Most patients without nephropathy had been treated by twice-daily soluble insulin for the whole or a substantial portion of their diabetic lives (Table 1). In contrast, in the group developing nephropathy the insulin regimen which had most commonly been prescribed was once-daily insulin-zinc suspension.

\section{Ketoacidosis}

In the group with diabetic nephropathy, 14 out of 23 patients had been admitted on 63 occasions with ketoacidosis. In the group without nephropathy, 13 out of 24 had been admitted on 31 occasions with ketoacidosis. The median frequency of ketoacidosis per year of diabetic life was $3 \times 10^{-2}$ (range $0-1.38$ ) for patients with nephropathy and $1.9 \times 10^{-2}$ (range $0-0.24$ ) for patients without nephropathy. The difference between the groups was not significant $(p>0.1$, Mann-Whitney $U$ test).

\section{Hypoglycaemia}

Ten out of 23 patients with diabetic nephropathy had been brought to hospital on 46 occasions with hypoglycaemia. Fourteen out of 24 without nephropathy had been brought to hospital on 43 occasions with hypoglycaemia. The median frequency of hospital visits with hypoglycaemia per year of diabetic life was 0 (range $0-1.11$ ) for patients with nephropathy and 0.02 (range $0-0.24$ ) for patients without nephropathy. The difference between the groups was not significant $(p>0.1$, Mann-Whitney U test).

\section{Other clinical information}

There were no significant differences between the groups with and without nephropathy in social class structure, smoking habits, alcohol consumption, or family history of Type 1 diabetes in first-degree relatives. 
With the exception of one patient with nephropathy whose non-diabetic brother suffered an isolated attack of 'nephritis' at the age of 25 years, there was no known family history of renal disease in either group. Autoimmune thyroid disease was present in two diabetic patients with nephropathy (one of whom also suffered from Addison's disease and pernicious anaemia) and four without nephropathy.

\section{Discussion}

We have not found any significant differences in frequency of any HLA antigen or Bf allotype between patients with nephropathy and control subjects. In particular, the lower frequency of DR4 in the group with nephropathy than in those without nephropathy suggests that DR4 does not predispose to nephropathy in Type 1 diabetes. However, in view of the relatively small number of patients studied and the small but not significant excess of patients with nephropathy who had B8, $\mathrm{DR} 3$ or $\mathrm{BfFl}$, we cannot exclude the possibility that possession of the B8-DR3 or B18-DR3-BfFl haplotypes influences the susceptibility to or rate of progression of nephropathy in sub-sets of Type 1 diabetic patients bearing these haplotypes.

Previously Jervell and Solheim [14] reported that in Scandinavia, the distribution of HLA-B antigens in Type 1 diabetic patients who had received renal transplants for terminal uraemia did not differ significantly from the distribution in a sample of patients with Type 1 diabetes from Copenhagen. Barbosa et al. reported an association of B8 with nephropathy [15], but, in a later study using a control group, Barbosa found no significant HLA-A or -B association with nephropathy in patients with Type 1 diabetes diagnosed before the age of 40 years [16]. These previous studies examined patients with Type 1 diabetes and terminal uraemia, a selected group in that some patients with diabetic nephropathy die of vascular causes before reaching advanced renal failure. Our findings in nephropathy are similar to those of Bodansky et al. [9] who, in a large study of retinopathy in Type 1 diabetes, found no discernible relationship with HLA-A, -B, -C or -DR phenotypes, but higher glycosylated haemoglobin levels in patients with retinopathy.

We found that patients with Type 1 diabetes and nephropathy had higher mean blood glucose concentrations than those without nephropathy. Use of the mean blood glucose concentration as an index of previous diabetic control has been supported by others [17, 18], and we were careful to collect only blood glucose values obtained at diabetic clinics before the diagnosis of microvascular disease. Therefore our findings are in agreement with Pirart's large prospective study [4], but contrast with the findings of Deckert et al. [5].

There was a preponderance of males in our patients with Type 1 diabetes both with and without nephropa- thy. It is known that there is a slight excess of males amongst patients who develop Type 1 diabetes before the age of 30 years [6], but males may also be at greater risk of developing nephropathy [19]. Our observation that the age of diagnosis of Type 1 diabetes was lower in patients with nephropathy is in agreement with Deckert et al. [20]. Despite much interest in the possibility of genetic heterogeneity within Type 1 diabetes [21], studies have failed to establish a relationship [6,22]. Our study provides no support for the hypothesis [5] that the relationship between a younger age of onset of Type 1 diabetes and nephropathy results from heterogeneity at the DR locus. Although the influence of age at onset of diabetes on the subsequent development of nephropathy could reflect the greater difficulties in obtaining good metabolic control in childhood and adolescence, we found no relationship between age at diagnosis of diabetes and mean blood glucose concentrations.

Like most long-term survivors of diabetes [2] most of our patients without nephropathy had received twicedaily soluble insulin. Lower mean glucose concentrations may therefore have resulted from more frequent insulin injections, as suggested by Tchobroutsky et al. [23]. In contrast to Christiansen and Nerup [24], we found no evidence of an association between smoking and diabetic nephropathy, nor were there any significant differences in body weight, insulin dosage, alcohol consumption, social class, family history of Type 1 diabetes in first-degree relatives, or prevalence of autoimmune thyroid disease between patients with and without nephropathy. Low blood flow [25] and low blood pressure [26] have been implicated as factors protecting against diabetic glomerulosclerosis. In view of the absence of blood pressure readings before development of nephropathy in several patients, and the differing age structures of our two groups, we did not attempt to assess the influence of blood pressure on the development of nephropathy.

Patients with Type 1 diabetes who have microalbuminuria detectable by radioimmunoassay and whose albumin excretion rates exceed $30 \mu \mathrm{g} / \mathrm{min}$ proceed to clinical nephropathy [27]. The albumin excretion rate correlates with percentage of glycosylated haemoglobin in these patients and can be lowered by continuous subcutaneous insulin infusion [28]. In our study a mean afternoon blood glucose concentration of $<11 \mathrm{mmol} / 1$ and an age at diagnosis of 16-29 years appeared to protect against the subsequent development of nephropathy. We cannot explain why, amongst patients with mean glucose concentrations $>11 \mathrm{mmol} / 1$, some did and others did not develop nephropathy, but there is no evidence that HLA antigens or Bf allotypes determined this divergence.

Acknowledgements. We wish to thank Dr. D. Longson and Dr. D. Davies for allowing us to study patients under their care; the several physicians who allowed us access to patients' notes; Miss L. Hunt and Dr. A. Read for statistical advice; Miss A.Halsall and Miss T. M. Wright for invaluable secretarial assistance. 


\section{References}

1. Balodimos MC (1971) Diabetic nephropathy. In: Marble A, White P, Bradley RF, Krall LP (eds) Joslin's diabetes mellitus. Lea \& Febiger, Philadelphia, pp 526-561

2. Oakley WG, Pyke DA, Tattersall RB, Watkins PJ (1974) Long-term diabetes; a clinical study of 92 patients after 40 years. Q J Med 43: $145-156$

3. Paz-Guevara AT, Hsu TH, White P (1975) Juvenile diabetes after 40 years. Diabetes 24:559-565

4. Pirart J (1978) Diabetes mellitus and its degenerative complications; a prospective study of 4,400 patients observed between 1947 and 1973. Diabetes Care 1: 168-188, 256-263

5. Deckert T, Poulsen JE (1981) Diabetic nephropathy; fault or destiny? Diabetologia 21: 178-183

6. Cudworth AG, Bottazzo GF, Doniach D (1980) Genetic and immunological factors in Type 1 diabetes. In: Irvine J (ed) The immunology of diabetes. Teviot Scientific Publications, Edinburgh, pp 67-99

7. Bertrams J, Dewald G, Spitznas M, Rittner C (1980) HLA-A, -B, $-\mathrm{C},-\mathrm{DR}, \mathrm{Bf}$ and $\mathrm{C} 2$ alleles in insulin-dependent diabetes mellitus with proliferative retinopathy. Immunobiology 158: 113-118

8. Dornan TL, Ting A, McPherson CK, Peckar CO, Mann JI, Turner RC, Morris P (1982) Genetic susceptibility to the development of retinopathy in insulin-dependent diabetics. Diabetes 31: 226-231

9. Bodansky HJ, Wolf E, Cudworth AG, Dean BM, Nineham LJ, Bottazzo GF, Matthews JA, Kurtz AB, Kohner EM (1982) Genetic and immunologic factors in microvascular disease in Type 1 insulin-dependent diabetes. Diabetes 31:70 74

10. Klouda PT, Manos J, Acheson EJ, Dyer PA, Goldby FS, Harris R, Lawler W, Mallick NP, Williams G (1979) Strong association between idiopathic membranous nephropathy and HLA-DRw3. Lancet 2: 770-771

11. Wooley PH, Griffin J, Panayi GS, Batchelor JR, Welsh KI, Gibson TJ (1980) HLA-DR antigens and toxic reaction to sodium auriothiomalate and $\mathrm{D}$-penicillamine in patients with rheumatoid arthritis. N Engl J Med 303: 300-302

12. Danilovs JA, Ayoub G, Terasaki PI (1980) B lymphocyte isolation by thrombin-nylon wool. In: Terasaki PI (ed) Histocompatibility testing. UCLA Press, Los Angeles, pp 287-288

13. Varley H, Gowenlock AH, Bell M (1980) Practical clinical biochemistry, Vol 1, 5th edn. Heinemann, London

14. Jervell J, Solheim B (1979) HLA antigens in long-standing insulindependent diabetics with terminal nephropathy and retinopathy with and without loss of vision. Diabetologia 17: 391 (Letter)

15. Barbosa J, Noreen H, Goetz F, Simmons R, de Leiva A, Najarian J, Yunis E (1976) Histocompatibility antigens and diabetic microangiopathy. Tissue Antigens 7:233-237

16. Barbosa J (1981) Is diabetic microangiopathy genetically heterogenous? HLA and diabetic nephropathy. Horm Metab Res (Suppl) 11: $77-80$
17. Burditt AF, Caird FI, Draper GJ (1968) The natural history of diabetic retinopathy. Q J Med 37: 303-317

18. Dornan T, Mann JI, Turner RC (1982) Factors protective against retinopathy in insulin-dependent diabetics free of retinopathy for 30 years. Br Med J 285: 1073-1077

19. Cudworth AG, Bodansky HJ (1982) Genetic and metabolic factors in relation to the prevalence and severity of diabetic complications. In: Keen H, Jarrett J (eds) Complications of diabetes, 2nd edn. Edward Arnold, London, pp 1-18

20. Deckert T, Andersen AR, Christiansen JS, Andersen JK (1981) The course of diabetic nephropathy. Factors related to development. Acta Endocrinol (Copenh) Suppl 242: 14-15

21. Bottazzo GF, Cudworth AG, Moul DJ, Doniach D, Festenstein H (1978) Evidence for a primary autoimmune type of diabetes. $\mathrm{Br}$ Med J 2: 1253-1255

22. Platz P, Jakobsen BK, Morling N, Ryder LP, Svejgaard A, Thomsen M, Christy M, Kromann H, Benn J, Nerup J, Green A, Hauge M (1981) HLA-D and DR antigens in genetic analysis of insulin-dependent diabetes. Diabetologia 21: 108-115

23. Tchobroutsky G, Charitanski D, Blouquit Y, Papoz L, Soria J, Rosa J (1980) Diabetic control in 102 insulin-treated out-patients. Diabetologia 18: $447-452$

24. Christiansen JS, Nerup J (1978) Smoking and diabetic nephropathy. Lancet 1: 605 (Letter)

25. Berkmann J, Rifkin H (1973) Unilateral nodular diabetic glomerulosclerosis (Kimmelstiel-Wilson). Report of a case. Metabolism 22: 715-722

26. Mauer SM, Steffes MW, Azar S, Sandberg SK, Brown DM (1978) The effect of Goldblatt hypertension on development of the glomerular lesions of diabetes mellitus in the rat. Diabetes 27: $738-744$

27. Viberti GC, Hill RD, Jarrett RJ, Argyropoulos A, Mahmud U, Keen H (1982) Microalbuminuria as a predictor of clinical nephropathy in insulin-dependent diabetes mellitus. Lancet 1: $1430-1432$

28. Viberti GC, MacKintosh D, Bilous RW, Pickup JC, Keen H (1982) Proteinuria in diabetes mellitus: role of spontaneous and experimental variation of glycaemia. Kidney Int $21: 714-720$

Received: 7 October 1983

and in revised form: 17 April 1984

Dr. C. Walton

c/o Dr. S.Oleesky

M3 Unit

Manchester Royal Infirmary

Oxford Road

Manchester 13 9WL

UK 